\title{
Towards Further Verification of Physiologically-Based Kidney Models: Predictability of the Effects of Urine-Flow and Urine-pH on Renal Clearance ${ }^{[\mathbf{s}}$
}

\author{
Takanobu Matsuzaki, ${ }^{1}$ @Daniel Scotcher, ${ }^{1}$ ๑ Adam S. Darwich, \\ (1)Aleksandra Galetin, and (1)Amin Rostami-Hodjegan \\ Centre for Applied Pharmacokinetic Research, University of Manchester, Manchester, United Kingdom (T.M., D.S., A.S.D., A.G., \\ A.R.-H.); Research Laboratories for Development, Shionogi \& Co., Ltd., Osaka, Japan (T.M.); and Simcyp Limited (A Certara \\ Company), Sheffield, United Kingdom (A.R.-H.)
}

Received June 28, 2018; accepted November 5, 2018

\section{ABSTRACT}

In vitro-in vivo extrapolation (IVIVE) of renal excretory clearance $\left(C L_{R}\right)$ using the physiologically based kidney models can provide mechanistic insight into the interplay of multiple processes occurring in the renal tubule; however, the ability of these models to capture quantitatively the impact of perturbed conditions (e.g., urine flow, urine $\mathrm{pH}$ changes) on $\mathrm{CL}_{\mathrm{R}}$ has not been fully evaluated. In this work, we aimed to assess the predictability of the effect of urine flow and urine $\mathrm{pH}$ on $\mathrm{CL}_{\mathrm{R}}$ and tubular drug concentrations (selected examples). Passive diffusion clearance across the nephron tubule membrane was scaled from in vitro human epithelial cell line Caco-2 permeability data by nephron tubular surface area to predict the fraction reabsorbed and the $C L_{R}$ of caffeine, chloramphenicol, creatinine, dextroamphetamine, nicotine, sulfamethoxazole, and theophylline. $\mathrm{CL}_{\mathrm{R}}$ values predicted using mechanistic kidney model at a urinary $\mathrm{pH}$ of 6.2 and 7.4 resulted in prediction bias of 2.87- and 3.62-fold, respectively. Model simulations captured urine flow-dependent $\mathrm{CL}_{R}$, albeit with minor underprediction of the observed magnitude of change. The relationship between drug solubility, urine flow, and urine $\mathrm{pH}$, illustrated in simulated intratubular concentrations of acyclovir and sulfamethoxazole, agreed with clinical data on tubular precipitation and crystal-induced acute kidney injury. This study represents the first systematic evaluation of the ability of the mechanistic kidney model to capture the impact of urine flow and urine $\mathrm{pH}$ on $\mathrm{CL}_{R}$ and drug tubular concentrations with the aim of facilitating refinement of IVIVE-based mechanistic prediction of renal excretion.

\section{Introduction}

Together with the liver, the kidneys play a principal role in the excretion of a wide variety of xenobiotics, including drugs, metabolites, and toxins, as well as endogenous compounds. Renal excretion can be defined as the elimination of unchanged solutes from the blood into the urine as a net result of the processes of glomerular filtration, tubular secretion, and tubular reabsorption (Tucker, 1981).

Passive tubular reabsorption is a major process that controls the extent of renal excretion of many substances (Varma et al., 2009; Scotcher et al., 2016b). The magnitude of passive reabsorption depends on the lipophilicity and extent of ionization of a drug and physiologic properties, such as urine flow rate and the

${ }^{1}$ T.M. and D.S. equally contributed to this work.

T.M. is an employee of Shionogi \& Co., Ltd. D.S. was supported by a Ph.D. studentship from the Biotechnology and Biological Sciences Research Council UK [BB/J500379/1] and AstraZeneca. A.R.-H. is an employee of Simcyp Limited (A Certara Company).

https://doi.org/10.1124/jpet.118.251413.

S This article has supplemental material available at jpet.aspetjournals.org.
$\mathrm{pH}$ of the luminal fluid in the renal tubule (Tang-Liu et al., 1983). Urine flow and urine $\mathrm{pH}$-dependent $\mathrm{CL}_{\mathrm{R}}$ have been reported for several drugs (Beckett et al., 1969; Sharpstone, 1969; Tang-Liu et al., 1982; Blanchard and Sawers, 1983; Birkett and Miners, 1991). Such trends are often mechanistically rationalized by the Henderson-Hasselbalch equation as arising from perturbed tubular reabsorption (Tucker, 1981; Molander et al., 2001).

In addition, urine flow and urine $\mathrm{pH}$ can be important contributors to renal toxicity risk. Sulfamethoxazole and acyclovir are low-solubility compounds, and crystalluria leading to acute kidney injury (AKI) reported for these drugs has been attributed to changes in urine flow and urine $\mathrm{pH}$ (Perazella, 1999). Direct measurement of the concentration of drugs in renal tubules compared with compound solubility properties may be beneficial in managing such risk. In the absence of direct measurements of intratubular concentrations in humans, use of mechanistic models representing pharmacokinetic processes within the proximal tubules in a physiologically meaningful context may provide useful insights and inferences in a quantitative manner.

ABBREVIATIONS: AAFE, absolute average fold error; AFE, average fold error; $\mathrm{AKI}$, acute kidney injury; $\mathrm{CL}_{\text {intefflux }}$, intrinsic efflux clearance;

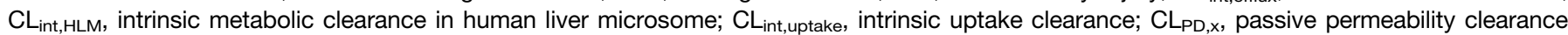
across membrane $\mathrm{x} ; \mathrm{CL}_{R}$, renal excretion clearance; DT, distal tubule; IVIVE, in vitro to in vivo extrapolation; LoH, loop of Henle; MATE, multidrug and toxin extrusion protein; MCD, medullary collecting ducts; MechKiM, mechanistic kidney model; OAT, organic anion transporters; $P_{\text {app }}$, apparent permeability; PBPK, physiologically based pharmacokinetics; PT, proximal tubule; $V_{\text {ss, }}$ volume of distribution at steady state. 
To predict human renal excretion clearance $\left(\mathrm{CL}_{\mathrm{R}}\right)$, an in vitro-in vivo extrapolation (IVIVE)-based approach using a mechanistic renal tubular reabsorption model was previously reported and validated with a set of 45 drugs that undergo limited secretion (Scotcher et al., 2016b). Advantages of this model include separation of drug- and physiologic/ system-specific information, which allows potential extrapolation to populations with different pathophysiologic features. Despite its physiologic nature, an important limitation of this static model was that urine flow-dependent $\mathrm{CL}_{\mathrm{R}}$ could not be adequately described, which also limits simulation of intratubular drug concentrations.

Theoretically, mechanistic kidney models developed within a physiologically based pharmacokinetic (PBPK) modeling framework can resolve the preceding limitations; however, these models typically include a large number of parameters, and measured data to inform some of the system (physiologic) parameters may not exist (e.g., proximal tubule cellularity) or are associated with uncertainty (e.g., renal transporter abundances) (Neuhoff et al., 2013; Scotcher et al., 2016a). In addition, some parameters may exhibit biologic variability that is not controlled or monitored in a typical clinical study; for example, urinary $\mathrm{pH}$ can range from 4.5 to 8 , but it is generally slightly acidic (i.e., 5.5-7.0) because of metabolic activity (Simerville et al., 2005). Another challenge with such complex models is ensuring the identifiability of parameters as plasma concentration-time data may not always be informative for all model parameters (Hsu et al., 2014; Huang and Isoherranen, 2018), as discussed previously (Tsamandouras et al., 2015; Scotcher et al., 2017; Guo et al., 2018). All the preceding challenges are also applicable in the case of renal elimination, especially when attempting to separate quantitatively the roles of active transport and passive permeability to overall secretion and/or reabsorption (e.g., salicylic acid, creatinine). Therefore, independent verification of specific model assumptions relating to passive permeability of drugs in the kidney would be of benefit since this is currently lacking.

The overall aim of this study was to assess the accuracy of a mechanistic kidney model for simulation of $\mathrm{CL}_{R}$ and intratubular concentrations under perturbed conditions, particularly changes in urine flow and urine $\mathrm{pH}$, when only effects relating to passive permeability were considered. Mechanistic description of active processes was not addressed; readers interested in this topic are directed elsewhere (Hsu et al., 2014; Posada et al., 2015; Ball et al., 2017). The accuracy of IVIVE-based predictions of both $\mathrm{CL}_{R}$ and fold changes in $\mathrm{CL}_{\mathrm{R}}$ from urine flow or $\mathrm{pH}$ changes was evaluated for caffeine, chloramphenicol, creatinine, dextroamphetamine, nicotine, sulfamethoxazole, and theophylline. Criteria for their selection included the availability of clinical data under perturbed conditions for $\mathrm{CL}_{\mathrm{R}}$, particularly changes in urine flow and urine $\mathrm{pH}$. Subsequently, the ability of the kidney model to simulate intratubular concentrations was investigated for low-solubility drugs acyclovir and sulfamethoxazole. The effects of variations in urine flow and urine $\mathrm{pH}$ were assessed to evaluate the likelihood of precipitation risk associated with crystalluria. Clinical reports on the effect of urine flow or $\mathrm{pH}$ changes on the occurrence of crystalluria for these two drugs were used for indirect validation of the simulated intratubular drug concentrations. Implications of the findings on the mechanistic prediction of tubular reabsorption and $\mathrm{CL}_{\mathrm{R}} \mathrm{using}$ IVIVE-PBPK modeling are discussed.

\section{Materials and Methods}

Development of Initial PBPK Model without Mechanistic Kidney Model. A literature search in PubMed identified seven drugs for which $\mathrm{CL}_{\mathrm{R}}$ and urine flow rates were simultaneously reported in the same subjects; these drugs were caffeine, chloramphenicol, creatinine, dextroamphetamine, nicotine, sulfamethoxazole, and theophylline. In addition, acyclovir and sulfamethoxazole were selected to assess the relationship between tubular concentrations and solubility owing to their association with crystalluria. Mean plasma concentration-time profiles and pharmacokinetic parameters were collated from the reported clinical studies (Table 1). Pharmacokinetic parameters of interest were the area under the curve for the plasma concentration-time profile, the intravenous clearance and apparent oral clearance, volume of distribution at steady state $\left(V_{\mathrm{ss}}\right)$ and $\mathrm{CL}_{\mathrm{R}}$. Where necessary, data were digitized using WebPlotDigitizer (versions 3.12 and 4.0, https://automeris.io/ WebPlotDigitizer). Where necessary, $\mathrm{CL}_{\mathrm{R}}$ values were calculated from the urinary excretion rate (urine concentration $\times$ urine flow rate) divided by its plasma concentration or total urine excretion amount divided by the area under the curve.

All simulations presented herein were performed using the Simcyp simulator, version 16, release 1 (Certara, Sheffield, UK) (Jamei et al., 2009, 2013). Drug-dependent parameters for the initial PBPK models without implementation of the MechKiM are listed in Supplemental Tables S1 and S2. All simulations were performed using the default "healthy volunteers" population template file in the Simcyp simulator. The workflow used for the refinement and verification of compound files in the full PBPK model, as required for use of MechKiM, is shown in Fig. 1.

For the whole-body PBPK models, distribution parameters-including $V_{\mathrm{ss}}$ and tissue-to-plasma partition coefficients $(\mathrm{Kp})$-were predicted using the modified Rodgers and Rowland method (Rodgers et al., 2005; Rodgers and Rowland, 2006; Gaohua et al., 2016). Predicted Kp values were optimized by an empirical scalar (same factor used for all tissues) to recover the observed $V_{\mathrm{ss}}$, as estimated from observed plasmaconcentration profiles using parameter estimation module in the simulator (weighted least-squares fitting, weighted by the reciprocal of the predicted value squared). No refinement of predicted Kp was necessary for creatinine $(\mathrm{Kp}$ scalar $=1)$. Metabolic clearance and $\mathrm{CL}_{\mathrm{R}}$ input parameters for the caffeine and theophylline PBPK models were not changed from the default values. The intrinsic hepatic metabolic clearance parameters (for amphetamine, chloramphenicol, and nicotine were obtained using back-calculation of $\mathrm{CL}_{\text {int }}$ from available intravenous clearance data using the well stirred model and correcting for $\mathrm{CL}_{\mathrm{R}}$.

After verification of the clearance and distribution parameters, first-order oral absorption model parameters, fraction absorbed $\left(\mathrm{F}_{\mathrm{a}}\right)$, and the absorption rate constant $\left(\mathrm{k}_{\mathrm{a}}\right)$ were optimized and verified for caffeine, creatinine, dextroamphetamine, and theophylline. Since the production rate of creatinine is reported to be $18.72 \mathrm{mg} / \mathrm{kg}$ per day in human (Boroujerdi, 1982), an i.v. infusion dosing of $18.72 \mathrm{mg} / \mathrm{kg}$ per day was implemented to mimic the production rate of creatinine. The cooked-meat meal is suggested to contain about $340 \mathrm{mg}$ of creatinine (Mayersohn et al., 1983); therefore, oral administration of $340 \mathrm{mg}$ of creatinine was assumed for this condition. Data used for verification were from independent clinical studies different from those used for parameter refinement and developing the model; details of clinical studies collated are listed in Table 1. During verification and refinement of PBPK models, simulations in 10 trials of virtual subjects were performed after trial designs (dosing route, amount, and frequency; number of individuals; and age of subjects) reported in the respective publications.

Prediction of Tubular Reabsorption in MechKiM: Physiologic Parameters and Scaling Approach. Previously reported IVIVE-based static tubular reabsorption model (Scotcher et al., 2016b) is a five-compartment mechanistic model comprising segments representing the glomerulus proximal tubule (PT), the loop of Henle $(\mathrm{LoH})$, the distal tubule (DT), and the collecting ducts (CD) (Scotcher et al., 2016b). In contrast, MechKiM comprises eight segments 
TABLE 1

Details of clinical studies used for verification and refinement of the physiologically based pharmacokinetics models for selected compounds

\begin{tabular}{|c|c|c|c|c|}
\hline Compound & Reference & Optimization/Verification & Dose Information & Subject Information \\
\hline \multirow[t]{5}{*}{ Caffeine } & Lelo et al. (1986) & Refinement & 270-mg oral SD & $6 \mathrm{M}, 19-21 \mathrm{yr}$ \\
\hline & Newton et al. (1981) & Verification & $50-\mathrm{mg}$ oral SD & $5 \mathrm{M}, 21-36 \mathrm{yr}$ \\
\hline & Newton et al. (1981) & Verification & $300-\mathrm{mg}$ oral SD & $5 \mathrm{M}, 1 \mathrm{~F}, 21-36 \mathrm{yr}$ \\
\hline & Newton et al. (1981) & Verification & 500-mg oral SD & $5 \mathrm{M}, 1 \mathrm{~F}, 21-36 \mathrm{yr}$ \\
\hline & Newton et al. (1981) & Verification & $750-\mathrm{mg}$ oral SD & $5 \mathrm{M}, 1 \mathrm{~F}, 21-36 \mathrm{yr}$ \\
\hline \multirow[t]{3}{*}{ Chloramphenicol } & Burke et al. (1982) & Refinement & $\begin{array}{l}\text { CAPS 502- to } 1324-\mathrm{mg} \text { i.v. infusion } \\
\text { for average of } 18 \mathrm{~min} \text { SD }\end{array}$ & $3 \mathrm{M}, 5 \mathrm{~F}, 19-64 \mathrm{yr}$ \\
\hline & Mikami et al. (1975) & Verification & $1000-\mathrm{mg}$ i.v. SD, bolus (1 $\mathrm{min})$ & $15 \mathrm{M}, 40-53 \mathrm{yr}$ \\
\hline & Nahata and Powell (1981) & Verification & CAPS $100-\mathrm{mg} / \mathrm{kg}$ per day i.v. infusion over $0.5 \mathrm{~h}$ & $1 \mathrm{M}, 20 \mathrm{yr}$ \\
\hline \multirow[t]{2}{*}{ Creatinine } & Mayersohn et al. (1983) & Verification & Baseline & $6 \mathrm{M}, 26-38 \mathrm{yr}$ \\
\hline & Mayersohn et al. (1983) & Verification & Cooked meat (340-mg oral) & $6 \mathrm{M}, 26-38 \mathrm{yr}$ \\
\hline \multirow[t]{4}{*}{ Dextroamphetamine } & Watanalumlerd et al. (2007) & Refinement & $20-$ or $30-\mathrm{mg}$ oral & Not reported \\
\hline & Beckett et al. (1969) & Refinement & $8.7-\mathrm{mg}$ oral SD & $2 \mathrm{M}, 21$ and $23 \mathrm{yr}$ \\
\hline & Dolder et al. (2017) & Verification & $29.6-\mathrm{mg}$ oral SD & $12 \mathrm{M}, 12 \mathrm{~F}, 21-34 \mathrm{yr}$ \\
\hline & Wan et al. (1978) & Verification & 10-mg oral SD & $4 \mathrm{M}, 1 \mathrm{~F}, 22-26 \mathrm{yr}$ \\
\hline \multirow[t]{3}{*}{ Nicotine } & Molander et al. (2001) & Refinement & $0.028-\mathrm{mg} / \mathrm{kg}$ i.v. infusion for $10 \mathrm{~min} \mathrm{SD}$ & $10 \mathrm{M}, 10 \mathrm{~F}, 22-43 \mathrm{yr}$ \\
\hline & Benowitz and Jacob (1993) & Refinement & $0.015-\mathrm{mg} / \mathrm{kg}$ i.v. infusion for $30 \mathrm{~min} \mathrm{SD}$ & $9 \mathrm{M}, 2 \mathrm{~F}, 22-58 \mathrm{yr}$ \\
\hline & Zevin et al. (1997) & Verification & $0.015-\mathrm{mg} / \mathrm{kg}$ i.v. infusion for $30 \mathrm{~min} \mathrm{SD}$ & $6 \mathrm{M}, 6 \mathrm{~F}, 18-47 \mathrm{yr}$ \\
\hline \multirow[t]{6}{*}{ Sulfamethoxazole } & Mannisto et al. (1982) & Refinement & $1000-\mathrm{mg}$ i.v. infusion for $60 \mathrm{~min} \mathrm{SD}$ & $4 \mathrm{M}, 2 \mathrm{~F}, 22-31 \mathrm{yr}$ \\
\hline & Welling et al. (1973) & Refinement & $800-\mathrm{mg}$ oral SD & 6 subjects \\
\hline & Welling et al. (1973) & Refinement & 800-mg oral SD & 5 subjects \\
\hline & Hutabarat et al. (1991) & Verification & $10-\mathrm{mg} / \mathrm{kg}$ i.v. infusion for $60 \mathrm{~min} \mathrm{SD}$ & $7 \mathrm{M}, 1 \mathrm{~F}, 22-27 \mathrm{yr}$ \\
\hline & Kaplan et al. (1973) & Verification & $2000-\mathrm{mg}$ oral SD & $24 \mathrm{M}$ \\
\hline & Kaplan et al. (1973) & Verification & $2000-m g$ oral SD & $8 \mathrm{M}$ \\
\hline \multirow{5}{*}{ Theophylline } & Lelo et al. (1986) & Refinement & $250-\mathrm{mg}$ oral SD & $6 \mathrm{M}, 19-21 \mathrm{y}$ \\
\hline & Rovei et al. (1982) & Verification & $125-\mathrm{mg}$ oral SD & $4 \mathrm{M}, 4 \mathrm{~F}, 22-35 \mathrm{yr}$ \\
\hline & Rovei et al. (1982) & Verification & $250-\mathrm{mg}$ oral SD & $4 \mathrm{M}, 4 \mathrm{~F}, 22-35 \mathrm{yr}$ \\
\hline & Rovei et al. (1982) & Verification & $375-\mathrm{mg}$ oral SD & $4 \mathrm{M}, 4 \mathrm{~F}, 22-35 \mathrm{yr}$ \\
\hline & Rovei et al. (1982) & Verification & $500-\mathrm{mg}$ oral SD & $4 \mathrm{M}, 4 \mathrm{~F}, 22-35 \mathrm{yr}$ \\
\hline \multirow[t]{11}{*}{ Acyclovir } & Blum et al. (1982) & Refinement & 0.5 - to $15-\mathrm{mg} / \mathrm{kg}, 1$ - or 6 -h infusion & Not reported \\
\hline & Soul-Lawton et al. (1995) & Refinement & 350-mg, 1-h infusion & $4 \mathrm{M}, 8 \mathrm{~F}, 23-50 \mathrm{yr}$ \\
\hline & Brigden et al. (1981) & Verification & 50 -mg i.v. bolus SD & $6 \mathrm{M}, 26-38 \mathrm{yr}$ \\
\hline & Brigden et al. (1981) & Verification & 50-mg i.v. $1 \mathrm{~h}$ infusion & $2 \mathrm{M}, 26-38 \mathrm{yr}$ \\
\hline & Brigden et al. (1981) & Verification & 50 -mg i.v. $10 \mathrm{~min}$ infusion & $2 \mathrm{M}, 26-38 \mathrm{yr}$ \\
\hline & de Miranda et al. (1981) & Verification & $0.5-$ to $2.5-\mathrm{mg} / \mathrm{kg}$, i.v. infusion over $1 \mathrm{~h}$ & $1 \mathrm{M}, 4 \mathrm{~F}, 25-68 \mathrm{yr}$ \\
\hline & Laskin et al. (1982a) & Verification & $5-\mathrm{mg} / \mathrm{kg}$ i.v. infusion over $1 \mathrm{~h}$ & $1 \mathrm{M}, 2 \mathrm{~F}, 24-67 \mathrm{yr}$ \\
\hline & Laskin et al. (1982b) & Verification & $2.5-\mathrm{mg} / \mathrm{kg}$, i.v. infusion over $1 \mathrm{~h}$ & $5 \mathrm{M}, 8 \mathrm{~F}, 23-76 \mathrm{yr}$ \\
\hline & Laskin et al. (1982b) & Verification & $5.0-\mathrm{mg} / \mathrm{kg}$, i.v. infusion over $1 \mathrm{~h}$ & $5 \mathrm{M}, 8 \mathrm{~F}, 23-76 \mathrm{yr}$ \\
\hline & Laskin et al. (1982b) & Verification & 10-mg/kg, i.v. infusion over $1 \mathrm{~h}$ & $5 \mathrm{M}, 8 \mathrm{~F}, 23-76 \mathrm{yr}$ \\
\hline & Laskin et al. (1982b) & Verification & $15-\mathrm{mg} / \mathrm{kg}$, i.v. infusion over $1 \mathrm{~h}$ & $5 \mathrm{M}, 8 \mathrm{~F}, 23-76 \mathrm{yr}$ \\
\hline
\end{tabular}

CAPS, chloramphenicol succinate; $\mathrm{F}$, female; $\mathrm{M}$, male; $\mathrm{SD}$, single dose.

representing the glomerulus, three subregions of PT (PT-1, PT-2, and PT-3), the $\mathrm{LoH}$, the DT, and the cortical and medullary collecting ducts (MCDs) (Neuhoff et al., 2013). The MechKiM parameterizes passive permeability of drugs across the tubular epithelium as permeability clearances through the apical $\left(\mathrm{CL}_{\mathrm{PD}}\right.$, apical $)$ and basolateral $\left(\mathrm{CL}_{\mathrm{PD}}\right.$, basal $)$ membranes rather than a "drug-specific" apparent permeability $\left(P_{\text {app }}\right)$ and a "system-specific" tubular surface area.

In this study, an IVIVE approach was adapted from the static model for prediction of passive tubular reabsorption (Scotcher et al., 2016b). $P_{\text {app }}$ values across Caco- 2 cell monolayers were obtained from various literature sources, and details for each individual drug investigated are listed in Supplemental Table S3. The passive permeability in MechKiM is applied to the unbound and un-ionized species. According to Henderson-Hasselbalch equations, chloramphenicol, dextroamphetamine, nicotine, and sulfamethoxazole are estimated to have a smaller fraction in un-ionized form at apical (donor side, $\mathrm{pH}$ 6.5) and basolateral side (receiver side, $\mathrm{pH}$ 7.4) in the $\mathrm{pH}$ gradient format of the Caco-2 permeability assay (Supplemental Fig. S1; Supplemental Table S4). In vitro $P_{\text {app }}$ measurements across Caco- 2 cell monolayers can be affected by the drug characteristics (e.g., lipophilicity, pKa, unbound fraction in buffer and cells, and unspecific adsorption to in vitro systems) and assay conditions (e.g., buffer $\mathrm{pH}$, rotation speeds, transporters, and density of cell monolayer). Full details of the assay conditions were not consistently reported alongside the Caco-2 $P_{\text {app }}$ data that were collected from the literature. Therefore, to calculate the $\mathrm{CL}_{\mathrm{PD}}$ used in MechKiM, the assumption was made that literature reported Caco- $2 P_{\text {app }}$ values were representative of the passive permeability of unbound and un-ionized drug.

The apparent membrane permeability was calculated on the basis that resistance is the inverse of permeability and by assuming that the membrane resistance associated with the Caco-2 cell monolayer is attributable to the sum of resistances associated with the apical and basolateral membranes (eq. 1) (Avdeef, 2012; Kramer, 2016). This method makes several assumptions: the permeability of drugs across the apical membrane is equal to that of the basolateral membrane; no significant accumulation or binding of drug within the cell; assay is performed under sink conditions and no relevant effects of the filter support, aqueous boundary layer or para-cellular pathway:

$$
\frac{1}{P_{a p p}}=\frac{2}{P_{m e m}}
$$

The apparent membrane permeability was scaled to $\mathrm{CL}_{\mathrm{PD}}$, apical and $\mathrm{CL}_{\mathrm{PD}}$, basal using regional tubular surface area (TSA), as IVIVE scaling factor for each $i$ th tubular section represented by the model (eq. 2):

$$
C L_{P D, i}=P_{m e m} \times T S A_{i}
$$

Tubular surface areas for each tubular section were recalculated to adapt to MechKiM from the reported values for the five-compartment model (Supplemental Table S5) (Scotcher et al., 2016b) and are listed in Table 2. The $\mathrm{CL}_{\mathrm{PD}}$ values for each drug are shown in Supplemental Table S6. 
Predictive performance of the model against $F_{\text {reab }}$ and $C_{R}$ parameters was assessed for several compounds. The focus of the work was on renal elimination and corresponding changes in $\mathrm{CL}_{\mathrm{R}}$; therefore, the predictive performance of plasma concentration-time profiles was not assessed. Transporter contribution was assumed to be negligible for the compounds investigated. Although in vitro data indicate involvement of renal transporters in some instances (e.g., creatinine), the roles of filtration and/or passive permeability to renal elimination are expected to be dominant. Simulations were performed according to the reported clinical study designs in 10 trials of virtual subjects from the healthy volunteer population provided in the software. The effect of different assumed values for urinary $\mathrm{pH}$ on prediction of $\mathrm{CL}_{\mathrm{R}}$ was investigated by fixing the urine $\mathrm{pH}$ parameter to 7.4 (Simcyp default value) or 6.2 (Rose et al., 2015). Owing to the lack of measured data on segmental filtrate $\mathrm{pH}$ in humans (Neuhoff et al., 2013), tubular $\mathrm{pH}$ was assumed to be the same as urinary $\mathrm{pH}$ in this study. To compare the predictability of different models, the prediction of $\mathrm{CL}_{\mathrm{R}}$ by the static model was also assessed, as described previously (Scotcher et al., 2016b). The tubular surface area and tubular flow rate values used for the static model are listed in Supplemental Table S7.

Development of PBPK Model for Acyclovir in MechKiM and Consideration of Active Secretion. Acyclovir is rapidly excreted in the urine via glomerular filtration and tubular secretion via renal transporters, including organic anion transporter (OAT)1, OAT2, OAT3, multidrug and toxin extrusion (MATE)1, and MATE2-K (Takeda et al., 2002; Tanihara et al., 2007; Ito et al., 2010; Cheng et al., 2012; Ye et al., 2012, 2013; Mathialagan et al., 2017). The predicted $\mathrm{CL}_{\mathrm{R}}$ value of acyclovir in MechKiM without considering renal transporters (i.e., filtration clearance only) was $115 \mathrm{ml} / \mathrm{min}$, thereby underpredicting the observed $\mathrm{CL}_{\mathrm{R}}$ value of $283 \mathrm{ml} / \mathrm{min}$ (Soul-Lawton et al., 1995) (Supplemental Table S8). Accurate mechanistic representation of transporter kinetics for acyclovir was out of the scope of this study, and therefore an operational model was developed to simulate this compound's active secretion. The operational model, featuring a single basolateral transporter-mediated uptake clearance and a single apical efflux clearance, was developed using a previously described stepwise approach (Hsueh et al., 2018). First, a $\mathrm{CL}_{\text {int, uptake }}$ value for uptake transport in the renal proximal tubules was determined by fitting the in vivo plasma concentration-time profile (Soul-Lawton et al., 1995) (weighted least-squares fitting, weighted by the reciprocal of the predicted value squared); a $\mathrm{CL}_{\text {int, efflux value }}$ of $1 \mu \mathrm{l} / \mathrm{min}$ per million proximal tubule cells was fixed as a reference value (Hsueh et al., 2018). Second, using the resulting $\mathrm{CL}_{\text {int, uptake }}$ value $\left(14.0 \mu \mathrm{l} / \mathrm{min}\right.$ per million proximal tubule cells), the $\mathrm{CL}_{\text {int, efflux }}$ value $(1.15 \mu \mathrm{l} / \mathrm{min}$ per million proximal tubule cells) was obtained by sensitivity analysis of the observed $\mathrm{CL}_{\mathrm{R}}$ data $(283 \mathrm{ml} / \mathrm{min}$ (Soul-Lawton et al., 1995)) (Supplemental Fig. S2). The simulated concentration-time profiles were in good agreement with observed data (Supplemental Fig. S3). Finally, observed acyclovir $\mathrm{CL}_{\mathrm{R}}$ data reported by other clinical studies were used for model verification (Supplemental Table S8).

Simulation of Urine Flow-Dependent $\mathbf{C L}_{\mathbf{R}}$. Effects of variations of urine flow on $\mathrm{CL}_{\mathrm{R}}$ were simulated for each drug using the virtual population representative (male, age 20 years, body weight $81 \mathrm{~kg}$ ) in a healthy volunteer population. Dosage information used for simulations is listed in Supplemental Table S9. Urine and tubule $\mathrm{pH}$ values of 4.5, 6.2, and 8.0 were used to investigate the impact of the fraction of drug as un-ionized species. The relative change in $\mathrm{CL}_{R}$ was calculated using $\mathrm{CL}_{\mathrm{R}}$ predicted when urine flow rate $=1 \mathrm{ml} / \mathrm{min}$ as baseline. Focus of the work was on relative changes as a result of perturbed renal elimination, analogous to approaches applied for 
TABLE 2

Tubular surface area used to calculate passive permeability clearance $\left(\mathrm{CL}_{\mathrm{PD}}\right)$ in mechanistic kidney model

Values recalculated from those reported for the five-compartment model (Scotcher et al., 2016b).

Tubular Surface Area $\left(\mathrm{cm}^{2} /\right.$ million tubule cells)

\begin{tabular}{ll}
\hline PT-1 & 2.98 \\
PT-2 & 2.98 \\
PT-3 & 2.98 \\
LoH & 0.0796 \\
DT & 0.101 \\
CCD & 0.0184 \\
MCD & 0.00374 \\
\hline
\end{tabular}

CCD, Cortical collecting duct; DT, distal tubule; LoH, loop of Henle; MCD, medullary collecting duct; PT, proximal tubule.

the evaluation of drug-drug or drug-disease interactions (e.g., (Yoshida et al., 2017). Changes in plasma drug concentrations from urine flow variations are typically small and not frequently reported and so were not evaluated in the current study. Baseline $\mathrm{CL}_{\mathrm{R}}$ at urine flow rate of $1 \mathrm{ml} / \mathrm{min}$ was calculated from reported clinical data over a flow range; details for individual drugs and clinical studies are shown in Supplemental Table S10.

Tubular flow-rate input parameter values used in the MechKiM and the static model are listed in Supplemental Tables S11 and S12, respectively. To maintain mass balance, Simcyp MechKiM tubular outflow rates were matched to the inflow rates of the subsequent tubule compartment. Therefore, the inflow rate to the first proximal tubule compartment was defined as the glomerular filtration rate and was set to $120 \mathrm{ml} / \mathrm{min}$. Bladder urine flow rates in MechKiM ranged from 0.1 to $20.0 \mathrm{ml} / \mathrm{min}$ to cover the range observed in clinical studies measuring $\mathrm{CL}_{\mathrm{R}}$; the adjusted flow-rate values were calculated by the Simcyp software for the remaining tubular compartments. In clinical observations, patients with reported acyclovir-induced AKI showed low urine output of approximately $0.1-0.2 \mathrm{ml} / \mathrm{min}$ (Giustina et al., 1988; Eck et al., 1991). Although higher urine flow rate values (up to approximately $28 \mathrm{ml} / \mathrm{min}$ ) have been reported in humans under extreme water diuresis, clinical $\mathrm{CL}_{\mathrm{R}}$ data under this condition were not found in literature (Supplemental Table S13).

In the case of the static tubular reabsorption model, midpoint flow rates were assumed for each tubular region; the highest flow rate investigated $(11.6 \mathrm{ml} / \mathrm{min})$ was determined by the assumed flow rate at the beginning of the collecting duct, and the urine flow rate range from 0.1 to $11.6 \mathrm{ml} / \mathrm{min}$. The flow rates for the remaining tubular regions were not changed in the static model assuming that changes to urine flow rate are mediated by changes to water permeability in only the collecting duct. This assumption is in accordance with current understanding of the physiologic regulation of water balance via a feedback mechanism involving osmoreceptor, arginine vasopressin, and aquaporin (Knepper et al., 2015).

Simulation of Urine pH-Dependent $\mathbf{C L}_{\mathbf{R}}$. Effects of variations of urine $\mathrm{pH}$ on $\mathrm{CL}_{\mathrm{R}}$ were simulated for each drug using a generic virtual study design of 10 trials of 10 subjects (proportion of females, 0.5 ; age, 20-50 years) in a healthy volunteer population. Dosage information for simulations is shown in Supplemental Table S9. The fluid $\mathrm{pH}$ at each tubule (PT, LoH, DT, and CD) varied from 4 to 9, assuming the same for urine $\mathrm{pH}$. Glomerular filtration rate values for virtual subjects were calculated using the Cockcroft-Gault equation, based on serum creatinine, age, and weight of the defined virtual population, and bladder urine flow rates were $1 \mathrm{ml} / \mathrm{min}$. Observed data obtained from the literature are listed in Supplemental Table S10. Data were presented graphically as fold changes in $C L_{R}$ from baseline values at either $1 \mathrm{ml} / \mathrm{min}$ urine flow rate or $\mathrm{pH}$ 6.2. As with the urine flow simulations, primary focus was on the magnitude of changes rather than the absolute values.

Simulation of Tubular Concentration for Acyclovir and Sulfamethoxazole. Acyclovir and sulfamethoxazole are associated with the precipitation of crystals in the distal tubular lumen, including collecting ducts in patients and nonhuman animals (Brigden et al., 1982; Tucker, 1982; Tucker et al., 1983; Sawyer et al., 1988; Perazella, 1999). To evaluate the relationship between tubular concentration and solubility, tubular concentrations of acyclovir and sulfamethoxazole were simulated using the population representative (a 20-yearold man; body weight, $81 \mathrm{~kg}$ ) in a healthy volunteer population. In addition, urine concentration was calculated from simulated excreted urine amount and urine flow rate by sampling at regular intervals for $0.25,1,3$, or 6 hours. The solubility of acyclovir is $2.5 \mathrm{mg} / \mathrm{ml}$ in water at $37^{\circ} \mathrm{C}$ (Arnal et al., 2008), and sulfamethoxazole shows $\mathrm{pH}$-dependent solubility $(0.51 \mathrm{mg} / \mathrm{ml}$ at $\mathrm{pH} 4.11,0.61 \mathrm{mg} / \mathrm{ml}$ at $\mathrm{pH} 5.48,8.25 \mathrm{mg} / \mathrm{ml}$ at $\mathrm{pH} 7.16,37.7 \mathrm{mg} / \mathrm{ml}$ at $\mathrm{pH} 7.79$ ) in aqueous buffer at $37^{\circ} \mathrm{C}$ (Dahlan et al., 1987). Urine flow rate for simulation was fixed to 1 (control), 0.2 (assuming volume depletion), or $5 \mathrm{ml} / \mathrm{min}$ (assuming fluid therapy). Urine $\mathrm{pH}$ used for acyclovir simulation was set at the median value of $\mathrm{pH} 6.2$, whereas a $\mathrm{pH}$ range between 4 and 8 was investigated for sulfamethoxazole due to urine $\mathrm{pH}$ sensitive $\mathrm{CL}_{\mathrm{R}}$.

Data Analysis. The predictability of the PBPK model and the other approaches was assessed by calculating the average fold error (AFE), the absolute average fold error (AAFE), and root mean square error, according to eq. $3-5$ :

$$
\begin{aligned}
A F E & =10^{\left(\frac{1}{n} \sum \log \left(\frac{\text { Predicted })}{\text { Observed }}\right)\right.} \\
A A F E & =10^{\left(\frac{1}{n} \sum\left|\log \left(\frac{\text { Predicted }}{\text { Oboserved }}\right)\right|\right)} \\
R M S E & =\sqrt{\frac{1}{n} \sum(\log (\text { Observed })-\log (\text { Predicted }))^{2}},
\end{aligned}
$$

where $n$ is the number of assessed studies for each drug. In addition, the percentage of studies within 2 -fold and 3 -fold was assessed by comparison of the predicted and observed pharmacokinetic parameters.

\section{Results}

PBPK Models without Mechanistic Kidney Model. Compound-specific input parameters for the developed PBPK models of the investigated drugs are listed in Supplemental Table S1 and S2. The simulated concentration-time profiles before activation of mechanistic kidney model were generally in good agreement with observed data for all drugs (Supplemental Fig. S4). Although some misspecification of the absorption phase may be apparent for some drugs (or could not be fully verified with available clinical data), accurate description of oral absorption was not considered an essential feature of the model for the purpose of the current study, and therefore further refinement of oral absorption was not performed.

Prediction of $\mathrm{CL}_{\mathbf{R}}$ Using Mechanistic Kidney Model. Subsequently, $\mathrm{CL}_{\mathrm{R}}$ was predicted using IVIVE of tubular reabsorption for seven drugs/endogenous molecules, namely, caffeine, chloramphenicol, creatinine, dextroamphetamine, nicotine, sulfamethoxazole, and theophylline. Predictions were performed using a mechanistic kidney model and following different urinary $\mathrm{pH}$ assumptions (Supplemental Fig. S5; Table 3). Urinary and tubular $\mathrm{pH}$ levels at average condition (i.e., without coadministration of ammonium chloride or sodium bicarbonate for urine acidification or alkalification, respectively) were assumed to be either 7.4 (Simcyp default value) or 6.2 (Rose et al., 2015). Overall predictability of $\mathrm{CL}_{\mathrm{R}}$ using the MechKiM model was poorer compared with the static model, reflected in the AAFE of 3.62, 2.87, and 1.97 
TABLE 3

Prediction accuracy of renal clearance of seven drugs predicted using mechanistic kidney model (MechKiM) and mechanistic renal tubular reabsorption model (static model)

For simulation using MechKim, urine/tubular $\mathrm{pH}$ at average condition was used as 7.4 (Simcyp default value) and 6.2 (Rose et al., 2015). Details of predictions are listed Supplemental Material, Supplemental Table S14.

\begin{tabular}{lccccc}
\hline & AFE & AAFE & RMSE & \% 2-fold & \% 3-fold \\
\hline MechKiM (pH 7.4) & 3.39 & 3.62 & 29.1 & 26.3 & 57.9 \\
MechKiM (pH 6.2) $^{2}$ & 2.69 & 2.87 & 37.9 & 52.6 & 68.4 \\
Static model $^{\alpha}$ & 1.42 & 1.97 & 18.4 & 68.4 & 73.7 \\
\hline
\end{tabular}

AAFE, absolute average fold error; AFE, average fold error; RMSE, root mean square error.

${ }^{a}$ Scotcher et al. (2016b)

for the MechKiM model at $\mathrm{pH} 7.4$ and 6.2, and the static reabsorption model, respectively (Table 3 ). Use of urinary $\mathrm{pH}$ of 6.2 improved the predictability of $\mathrm{CL}_{\mathrm{R}}$ using the mechanistic kidney model relative to $\mathrm{pH} 7.4$; however, these differences typically arose from relatively small differences in predicted $\mathrm{F}_{\text {reab }}$ (Supplemental Table S15). Urinary $\mathrm{pH}$ had no impact on simulated $\mathrm{CL}_{\mathrm{R}}$ for caffeine, creatinine, dextroamphetamine, and theophylline (Supplemental Fig. S5). Simulated $\mathrm{CL}_{\mathrm{R}}$ at $\mathrm{pH} 6.2$ was in better agreement with the observed data for chloramphenicol and sulfamethoxazole compared with pH 7.4, whereas opposite trends were seen for nicotine. Based on this analysis, pH 6.2 was used as baseline urine $\mathrm{pH}$ in MechKiM for subsequent simulations of the average condition.

As expected, simulation of acyclovir $\mathrm{CL}_{\mathrm{R}}$ without consideration of renal transporters resulted in a substantial underprediction of $\mathrm{CL}_{\mathrm{R}}$ (Supplemental Table S8). When renal transporters were accounted for using an operational model, simulated $\mathrm{CL}_{\mathrm{R}}$ of acyclovir was in close agreement with observed values (predicted/observed ratio: 0.93 ), and no impact of $\mathrm{pH}$ was noted. The simulated concentration-time profiles using MechKiM at urine $\mathrm{pH}$ of 6.2 are shown in Fig. 2. The simulations of systemic profiles were generally in agreement with the model where prediction of $\mathrm{CL}_{\mathrm{R}}$ was not done in a mechanistic manner.

Simulation of Urine Flow-Dependent $\mathbf{C L}_{\mathbf{R}}$. The impact of changes in urine flow rate on the simulated $\mathrm{CL}_{\mathrm{R}}$ of eight selected drugs was assessed (see Fig. 3) by changing the relevant tubular flow rate parameters in the mechanistic kidney model while keeping urine $\mathrm{pH}$ constant at 4.5, 6.2, and 8.0. Overall, prediction of changes in $\mathrm{CL}_{\mathrm{R}}$ at different urine flow rates by MechKiM showed better consistency with observed data than predictions using the static model. The model predictions identified caffeine, sulfamethoxazole, and theophylline as the compounds with the largest relative change in $\mathrm{CL}_{\mathrm{R}}$ resulting from changes in urine flow rate, in agreement with observed data; however, an overall underprediction of the magnitude of urine flow-dependent changes in $\mathrm{CL}_{\mathrm{R}}$ was apparent. This underprediction trend was particularly evident for sulfamethoxazole in the acidic urine condition. In the current data set, use of urinary $\mathrm{pH} 6.2$ resulted in the best agreement with predicted change in $\mathrm{CL}_{\mathrm{R}}$ for caffeine, creatinine, and theophylline. The simulated trend in $\mathrm{CL}_{\mathrm{R}}$ for chloramphenicol at urinary $\mathrm{pH} 4.5$ was generally in agreement with observed data. Although simulations for nicotine under acidic condition ( $\mathrm{pH} 4.5)$ predicted a urine flow-dependent $\mathrm{CL}_{R}$, the magnitude of this predicted effect was small. The large variability in the observed nicotine
$\mathrm{CL}_{\mathrm{R}}$ data and the small range of corresponding urine flow rates made it difficult to determine the true extent of covariability for this drug. No effects of urine flow on predicted $\mathrm{CL}_{\mathrm{R}}$ of creatinine and acyclovir were seen; these are lowpermeability compounds $\left(P_{\mathrm{app}}=1.08\right.$ and $0.291 \times 10^{-6} \mathrm{~cm} / \mathrm{s}$, respectively).

Simulation of Urine pH-Dependent $\mathbf{C L}_{\mathbf{R}}$. Simulated impact of changes in urine $\mathrm{pH}$ on the $\mathrm{CL}_{\mathrm{R}}$ of the eight drugs was also assessed (Fig. 4) by changing the urine and tubular fluid $\mathrm{pH}$ in MechKiM while keeping the urine flow rate constant at $1 \mathrm{ml} / \mathrm{min}$ in 100 virtual healthy subjects. Simulated $\mathrm{CL}_{\mathrm{R}}$ rates of chloramphenicol, nicotine, and sulfamethoxazole were sensitive to urine $\mathrm{pH}$ over the range of 4.5-8.0, whereas no effect was seen for remaining compounds. The trends in simulated $\mathrm{pH}$-dependent changes in $\mathrm{CL}_{\mathrm{R}}$ for sulfamethoxazole were largely in agreement with the observed data, although the observed trends for nicotine and dextroamphetamine were not recovered. In the cases of chloramphenicol, theophylline, and acyclovir, the accuracy of prediction could not be assessed because of a lack of clinical $\mathrm{CL}_{\mathrm{R}}$ values reported with corresponding urine $\mathrm{pH}$ data.

Simulation of Renal Tubular Concentrations of Acyclovir and Sulfamethoxazole. High-dose acyclovir was reported to result in crystal-induced AKI (Sawyer et al., 1988; Perazella, 1999). A low dose of this drug is typically well tolerated but can also cause AKI in the presence of severe volume depletion (urine output: $350 \mathrm{ml} / 24$ hours) (Giustina et al., 1988). Analogous to acyclovir, sulfamethoxazole can cause AKI in the presence of acidic urine $(\mathrm{pH}<7.15)$ (Perazella, 1999). Tubular concentrations of acyclovir and sulfamethoxazole were simulated by using doses for which crystal-induced AKI have been reported. Simulations of acyclovir PK and $\mathrm{CL}_{\mathrm{R}}$ at high doses $\left(500 \mathrm{mg} / \mathrm{m}^{2}\right.$ i,v. infusion, three times daily for 14 days) indicated that MCD was the tubular region with the highest $C_{\max }$ (Fig. 5A). The predicted acyclovir MCD tubular filtrate $C_{\max }$ was $4.69 \mathrm{mg} / \mathrm{ml}$ at normal urine flow rate $(1 \mathrm{ml} / \mathrm{min})$, which exceeds the reported aqueous solubility of $2.5 \mathrm{mg} / \mathrm{ml}$. Urinary concentrations calculated from simulated data for urine sampling every 0.25 hour were comparable to the simulated MCD tubule concentrations, whereas urine sampling at 3-hour intervals or longer showed less agreement (Fig. 5B). At a low dose $(5 \mathrm{mg} / \mathrm{kg}$ i.v. infusion, daily for 2 days) predicted concentrations of acyclovir in MCD tubule were below aqueous solubility at normal urine flow, but above aqueous solubility cut-off when urine flow was low $(0.2 \mathrm{ml} / \mathrm{min}$, Fig. $6 \mathrm{~A})$. Similarly, simulation of high dose (25 mg/kg four times daily for 14 days) of sulfamethoxazole with normal urine flow rate $(1 \mathrm{ml} / \mathrm{min})$ predicted $C_{\max }$ in MCD tubules equal to its solubility when pH $<7$ (Fig. 6B). In addition, low urine flow rate increased tubular concentration of sulfamethoxazole beyond its aqueous solubility limit. Simulation of high urine flow of $5 \mathrm{ml} / \mathrm{min}$ markedly decreased the $C_{\max }$ of acyclovir and sulfamethoxazole in MCD tubules; in this condition, their simulated tubular $C_{\text {max }}$ levels were below the solubility limit.

\section{Discussion}

Several mechanistic pharmacokinetic kidney models have been reported in the literature, with some recent efforts focusing predominantly on describing in vivo roles of transporter kinetics without mechanistically accounting for passive permeability (Felmlee et al., 2013; Neuhoff et al., 2013; Dave 

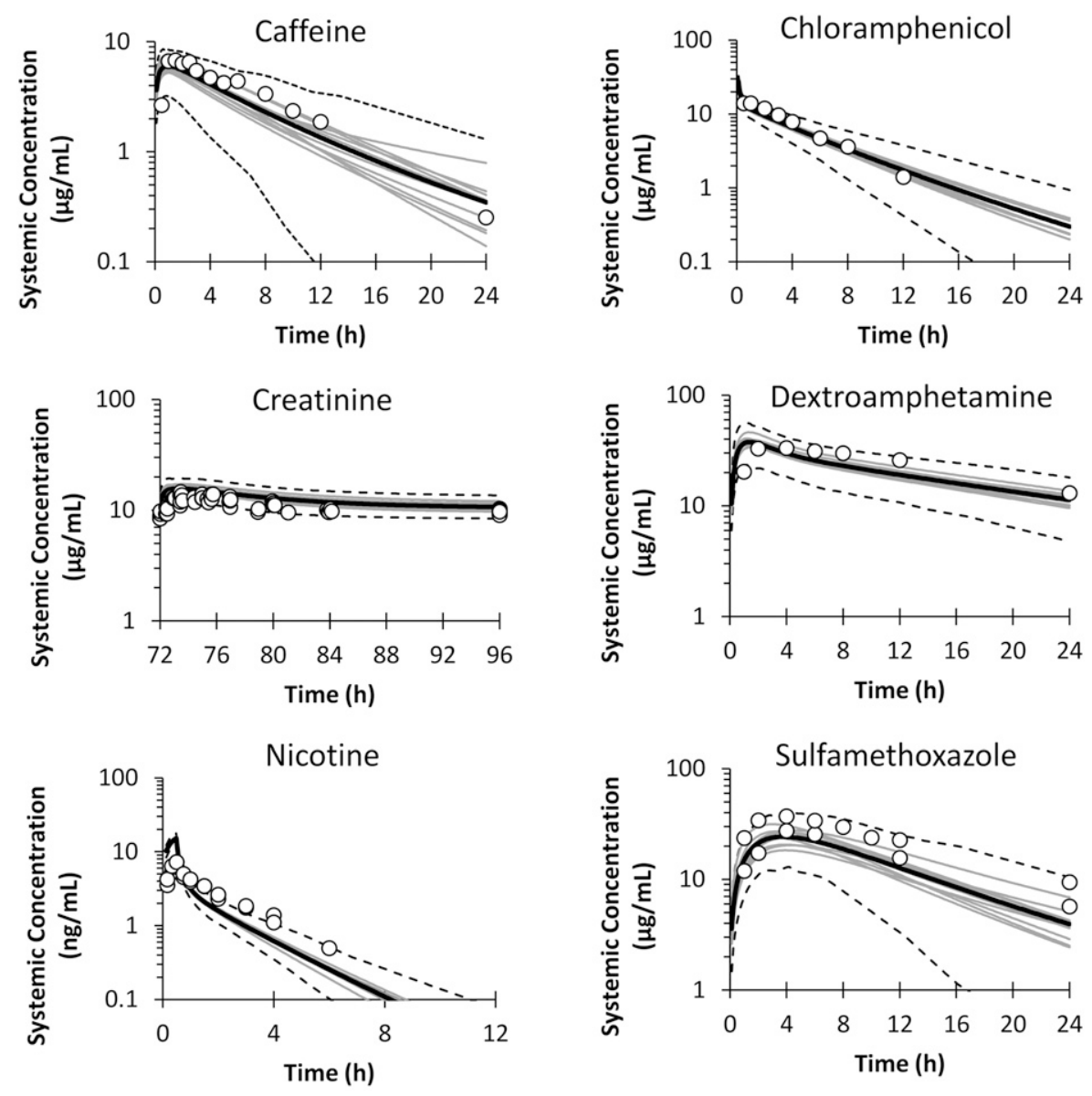

Fig. 2. Representative simulated plasma concentration-time profiles using PBPK models with MechKiM at a urine $\mathrm{pH}$ of 6.2. Bold black lines and dashed lines represent mean and 5th-95th percentile of 10 trials, respectively. Symbols indicate observed data.
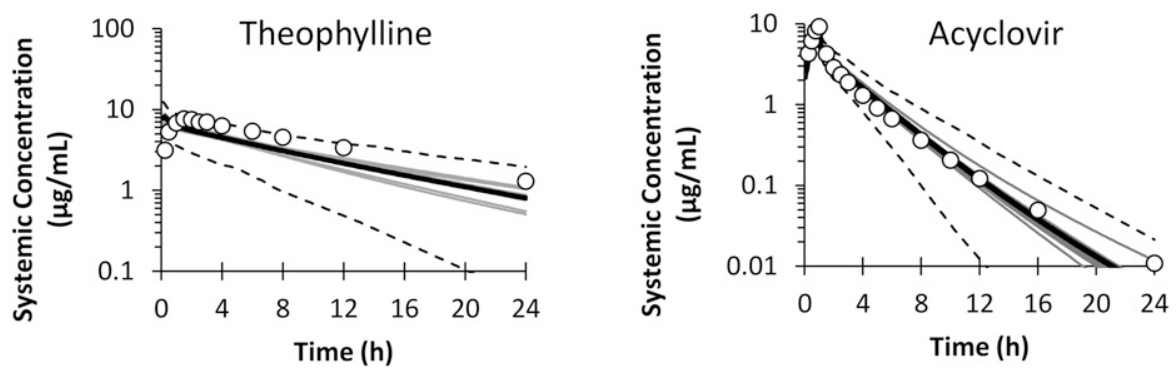

and Morris, 2015; Burt et al., 2016; Scotcher et al., 2017). Models developed for the purpose of describing passive tubular reabsorption have allowed simulation of urine flow-dependent $\mathrm{CL}_{\mathrm{R}}$ of drugs with different permeability properties (Tang-Liu et al., 1983; Komiya, 1986; Mayer et al., 1988); however, these models did not account for the varying physiology of the renal tubule in a mechanistic and quantitative manner and therefore lack the ability to simulate intra-tubular drug concentrations. Whereas a mechanistic kidney model implemented within the whole-body PBPK model in the Simcyp simulator could, in principle, overcome such limitations, the utility of this model for prediction of tubular reabsorption and effects of physiologic changes in urine flow and $\mathrm{pH}$ has not been demonstrated so far (Neuhoff et al., 2013).

In the current study, passive permeability parameters of the mechanistic kidney model were informed by IVIVE by adapting the scaling approach and regional tubular surface areas, as described previously (Scotcher et al., 2016b). Although analysis of the current data set showed a tendency for underprediction of observed $\mathrm{CL}_{\mathrm{R}}$, such mis-predictions are expected to have marginal consequence on the systemic exposure, as extensively reabsorbed drugs are often cleared mainly by nonrenal routes. Furthermore, apparently large differences in predicted and observed $\mathrm{CL}_{\mathrm{R}}$ rates for extensively reabsorbed compounds can arise from only minor mispredictions of the fraction reabsorbed (Supplemental Table S15). For example, underprediction of $\mathrm{F}_{\text {reab }}$ of 0.99 by $1 \%$ (i.e., predicted $\mathrm{F}_{\text {reab }}$ of 0.98 ) results in 2 -fold overprediction of $\mathrm{CL}_{\mathrm{R}}$ for a completely unbound drug. For average conditions, overall $\mathrm{CL}_{\mathrm{R}}$ predictions at $\mathrm{pH} 6.2$ (AAFE of 2.87) were more accurate than the assumption of urinary $\mathrm{pH}$ of 7.4 (AAFE of 3.62; Table 3), although nicotine was an exception to this trend (Supplemental Table S14). A more thorough evaluation of the IVIVE predictive performance of the mechanistic kidney model, with a larger data set of drugs, is required to confirm the trends observed here. Despite this discrepancy, predicted 

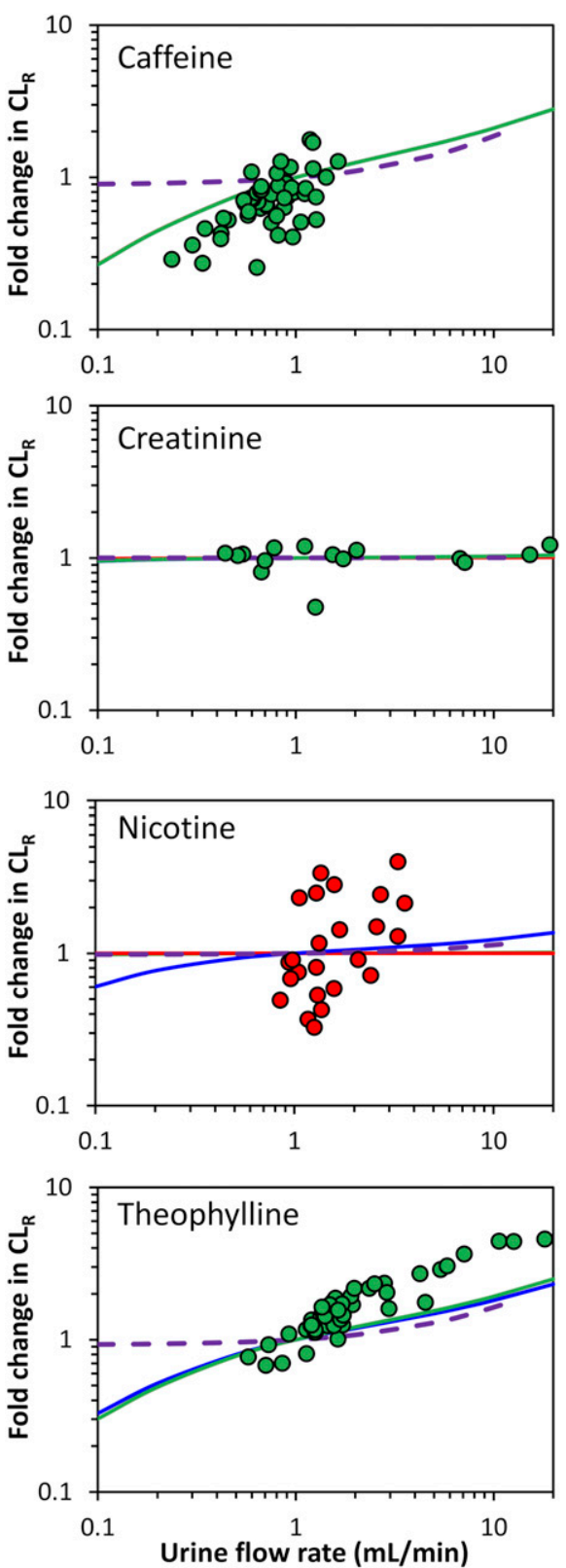
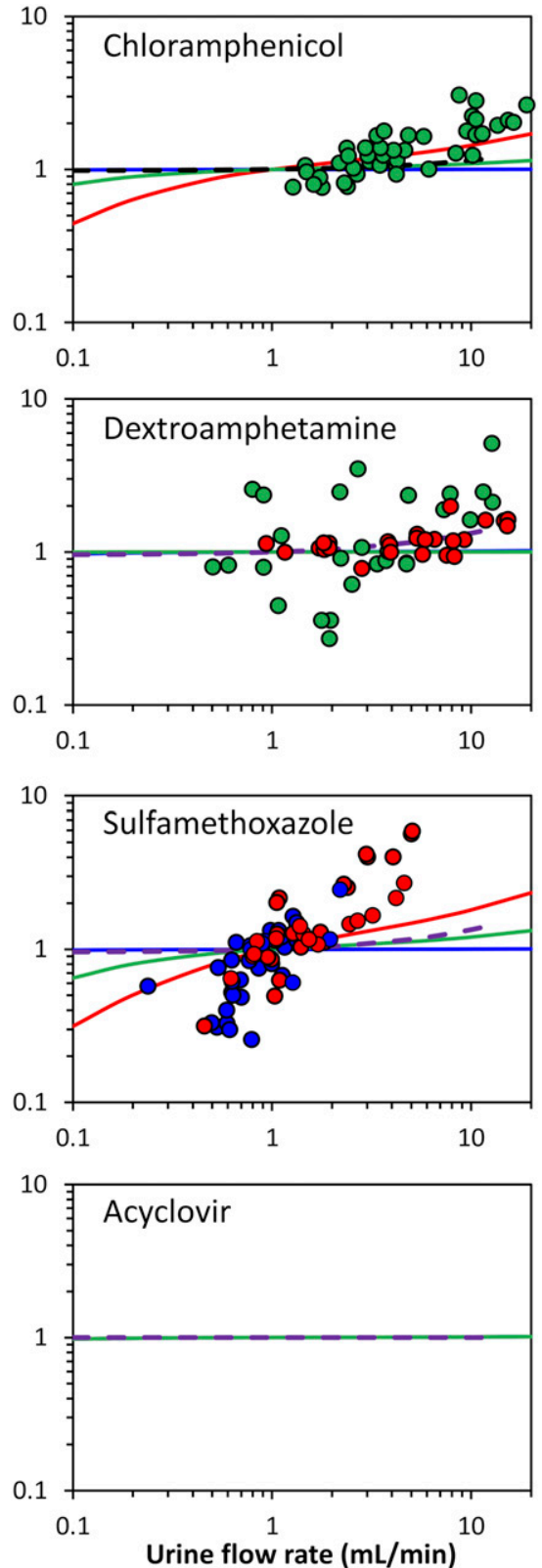

Fig. 3. Effect of urine flow on predicted $\mathrm{CL}_{\mathrm{R}}$ in virtual population representative at a tubule $\mathrm{pH}$ of 4.5 (red line), 6.2 (green line), and 8.0 (blue line) using MechKiM. Purpled dashed line represents predicted $C_{R}$ using the static model for comparison. Symbols indicate observed data with a urine $\mathrm{pH}$ of normal (green), acidic (red), and alkaline (blue) conditions. Fold change in simulated $\mathrm{CL}_{\mathrm{R}}$ (lines) of drugs was calculated using simulated $C_{R}$ at urine flow $=1 \mathrm{ml} / \mathrm{min}$ as baseline for each drug. The literature references for observed data are listed in Supplemental Table S10.
$\mathrm{CL}_{\mathrm{R}}$ for nicotine at both $\mathrm{pH}$ levels were within 3-fold of observed data.

Prediction of $\mathrm{CL}_{\mathrm{R}}$ using the static reabsorption model showed lower bias compared with MechKiM, despite using the same IVIVE scaling factors. The difference between the models may arise from different physiologic assumptions of each model, for example, MechKiM accounts for permeability across cell membranes, whereas static model considers permeability across epithelial cell monolayer; however, the static model has limited ability to simulate concentration-time profiles in renal tubules or account for compound ionization and permeability of different ionized species (Scotcher et al., 2016b).

The choice of in vitro permeability assay may be another consideration when evaluating the ability of kidney models to predict $\mathrm{CL}_{\mathrm{R}}$ and $\mathrm{F}_{\text {reab }}$ (Kunze et al., 2014; Scotcher et al., 2016b; Mathialagan et al., 2017). Colon-derived Caco-2 and other in vitro cell lines differ from heterogeneous epithelial cells constituting the nephron tubule in terms of tight junctions (affecting para-cellular drug permeability), transporter expression, and presence of microvilli. To address the latter, one study used an empirical surface-area scaling factor to recapitulate $\mathrm{CL}_{\mathrm{R}}$ from in vitro permeability data using a 35-compartment model (Huang and Isoherranen, 2018). No empirical scaling factor was applied in the current study; instead, the IVIVE approach relied on physiologic assumptions, although verification of each of the specific parameter values has not yet been achieved.

The mechanistic kidney model accurately identified drugs that exhibit urine flow- dependent $\mathrm{CL}_{\mathrm{R}}$, despite underprediction trends of the magnitude of the effect evident in some cases (Fig. 3). These underpredictions are likely related to the underprediction of the $\mathrm{F}_{\text {reab }}$ as discussed already herein. The model predicted that the $\mathrm{CL}_{\mathrm{R}}$ for drugs with higher 

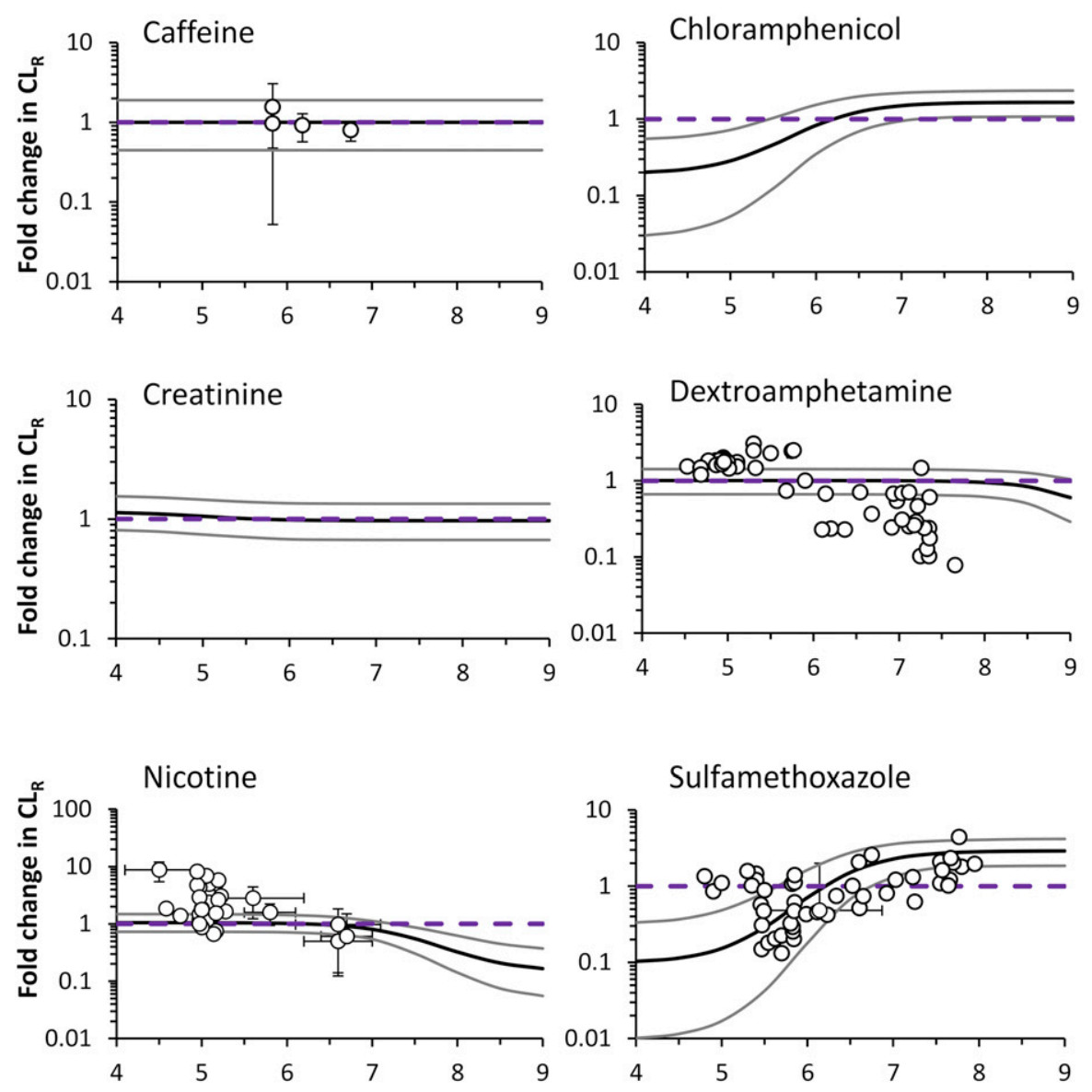

Fig. 4. Effect of urine $\mathrm{pH}$ on predicted $\mathrm{CL}_{\mathrm{R}}$ in a virtual healthy population (10 trials of 10 subjects) using MechKiM. Black and gray lines represent mean and 5th-95th percentile of 100 subjects, respectively. Purpled dashed line represents predicted $\mathrm{CL}_{\mathrm{R}}$ using the static model for comparison. Symbols indicate observed data for individuals or each study (mean \pm S.D.). The literature references for observed data are listed in Supplemental Table S10.
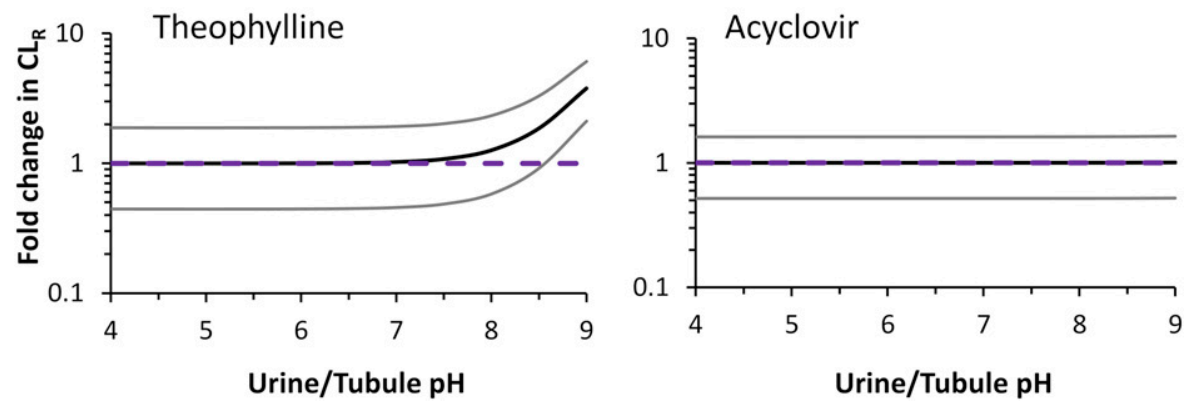

permeability would be the most sensitive to changes in urine flow, in agreement with previous studies (Tang-Liu et al., 1983; Komiya, 1986; Mayer et al., 1988). Conversely, a negligible effect of urine flow on $\mathrm{CL}_{\mathrm{R}}$ was predicted for lowpermeability compounds creatinine and acyclovir, in agreement with clinically reported data for creatinine (Tang-Liu et al., 1983). Although previously published kidney models have been able to capture the relationship between urine flow and $\mathrm{CL}_{\mathrm{R}}$ by fitting the model to observed data ("top-down" approach), they lacked the ability to simulate local concentrations in tubules (Tang-Liu et al., 1982, 1983).

According to Henderson-Hasselbalch equations, dextroamphetamine (pKa 10.1 for base) shows a low un-ionized fraction $(<1 \%)$ within a $\mathrm{pH}$ range of 4.5-8.0 (Supplemental Table S4). Simulated $\mathrm{CL}_{\mathrm{R}}$ for dextroamphetamine was sensitive to changes in urine $\mathrm{pH}$ only at $\mathrm{pH}>8$, in contrast to observed data in which $\mathrm{pH}$ sensitivity occurs across a broader range
(Fig. 4). Similar outcomes were found for nicotine, highlighting some uncertainty in the fraction of un-ionized across urine $\mathrm{pH}$ range and/or permeability of the ionized species. Measurement of intrinsic permeability of both un-ionized and ionized drug species may provide advantages over use of $P_{\text {app }}$; however, the former requires a more thorough experimental design and delineation of effects of assay conditions, in addition to factors like the binding of drugs to cellular proteins and lipids, organelle-specific partitioning of drugs, and transporter activities via mechanistic modeling (Neuhoff et al., 2003; Volpe, 2008; Avdeef, 2012; Zamek-Gliszczynski et al., 2013). This approach was not considered in the current study because of the disparate experimental conditions of the literature $P_{\text {app }}$ data collated. It is also recommended that such experiments be performed in the presence of a passive permeability marker and that transporter inhibitors be used in the assay media. 


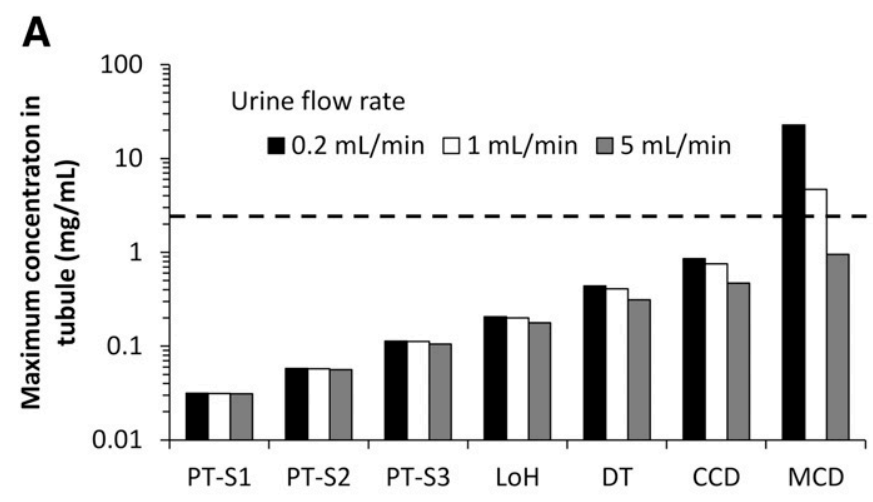

B

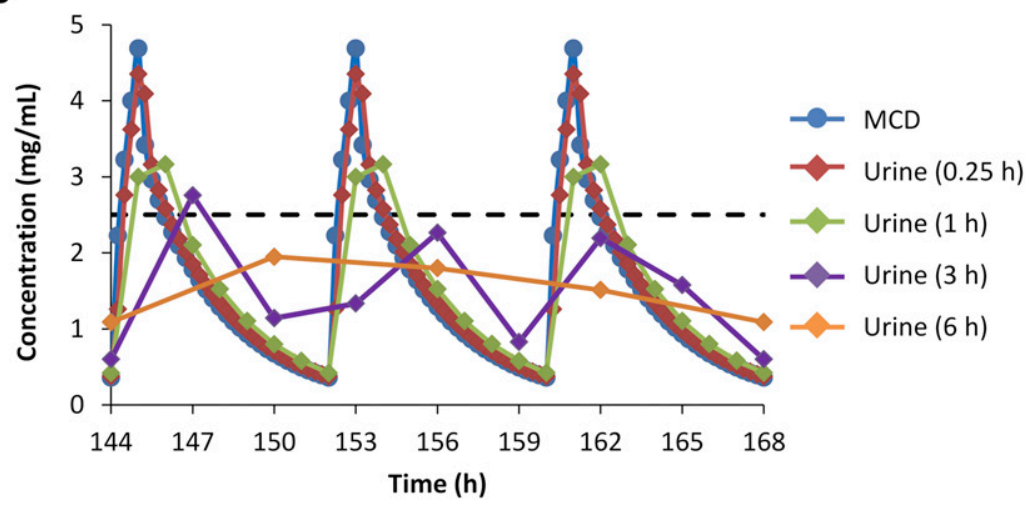

Fig. 5. Effect of urine flow on simulated renal tubular concentration of acyclovir at high-dose using MechKiM in virtual population representative. (A) Simulation of the maximum concentration of acyclovir in renal tubules after intravenously multiple administration of acyclovir at $500 \mathrm{mg} / \mathrm{m}^{2}$ i.v. infusion over 60 minutes every 8 hours for 7 days at urine flow of $0.2,1.0$, and $5.0 \mathrm{ml} / \mathrm{min}$. (B) Simulated concentration-time profiles of medullary collecting duct tubule and urine at urine flow of $1 \mathrm{ml} / \mathrm{min}$. Urine concentrations were calculated for urine collection intervals of $0.25,1,3$, or 6 hours. Horizontal dashed line represents the solubility of acyclovir $(2.5 \mathrm{mg} / \mathrm{ml})$.
In the current study, regional differences in filtrate $\mathrm{pH}$ were not considered because of the scarcity of relevant physiologic data. Micropuncture studies in rats have reported that the urine ( $\mathrm{pH}$ 6.1) is more acidic than the proximal tubule filtrate ( $\mathrm{pH}$ 6.7) in control conditions, but each of these can vary under different pathophysiologic states, such as acidosis (Malnic et al., 1972). Factors leading to an acidic urinary $\mathrm{pH}$ include a larger body weight, old age, and increased intake of meat (Rose et al., 2015), whereas alkaline urine was observed in patients with a urinary tract infection (Simerville et al., 2005). Clinical data show that urine $\mathrm{pH}$ can decrease to $<5.5$ in patients with chronic kidney disease (Kraut and Kurtz, 2005). In addition to tubular reabsorption, changes in filtrate $\mathrm{pH}$ may also affect activity of some transporters in vivo (e.g., MATE transporters); however, previous studies that used PBPK modeling to simulate the effect of renal insufficiency on pharmacokinetics of renally eliminated drugs assumed that $\mathrm{pH}$ of urine and tubular fluid were unaffected by disease (Hsu et al., 2014; Hsueh et al., 2018). All these findings highlight the importance of consideration of changes in urine $\mathrm{pH}$ and their impact on individual renal elimination processes when carrying out modeling and simulation within a PBPK framework, in particular for the prediction of drug exposure in specific patient populations.

The current study provides supporting evidence for the application of a mechanistic kidney model for simulation of drug concentrations in tubular filtrate in different regions of the nephron. Whereas data for preclinical species can be evaluated using experimental data obtained by invasive methods (e.g., micropuncture) (Senekjian et al., 1981), such data are not available for humans for ethical reasons. Therefore, indirect verification was performed using reported cases of drug-induced crystalluria-AKI. The relationship between solubility and simulated renal tubular concentration of acyclovir and sulfamethoxazole was in agreement with current clinical practices of managing the precipitation risk and the likelihood of crystal formation in MCD tubules by varying the urine flow rate and urine $\mathrm{pH}$. The analysis of simulated acyclovir concentrations in MCD tubule in different scenarios indicated that urine sampling every 0.25 hour would sufficiently capture the dynamic changes of MCD tubular concentrations, in contrast to urine sampling at every 3 hours (Fig. 5B). Considering the practical difficulties of collecting urine at such short intervals, simulation of tubular concentration using the PBPK modeling can be a useful tool for identify compounds and dosing regimens that would be at risk of crystalluria-AKI. Supporting information could also be obtained from further development and application of high spatial resolution bioimaging techniques (Notohamiprodjo et al., 2011).

In conclusion, the current study implemented an IVIVEPBPK approach for predicting the $\mathrm{CL}_{\mathrm{R}}$ of renally excreted drugs that undergo tubular reabsorption and after changes in urine flow and urine $\mathrm{pH}$. In addition, the mechanistic kidney model simulated the relationship between solubility and renal tubular concentration to rationalize and mitigate the risk of crystal-induced AKI. This comprehensive evaluation represents an additional step toward the qualification of mechanistic kidney models for studying the pharmacokinetic variability arising from different clinical scenarios and patient characteristics; however, uncertainty in the interindividual and intraindividual variability of regional tubular urine flow and tubular fluid $\mathrm{pH}$ remains. After further development, coupling of mechanistic kidney models for the prediction of pharmacodynamic and toxicity effects and the risk or probabilities of clinical outcomes under various scenarios are envisaged. 


\section{A Acyclovir}

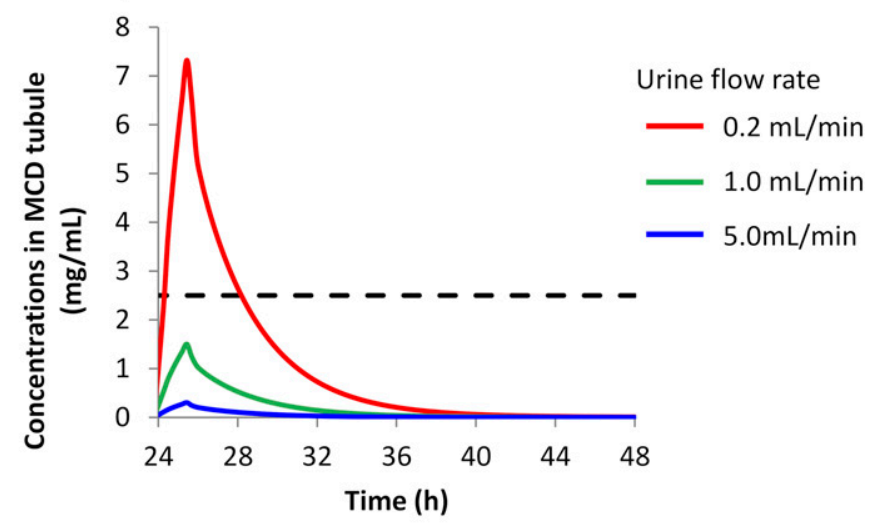

\section{B Sulfamethoxazole}

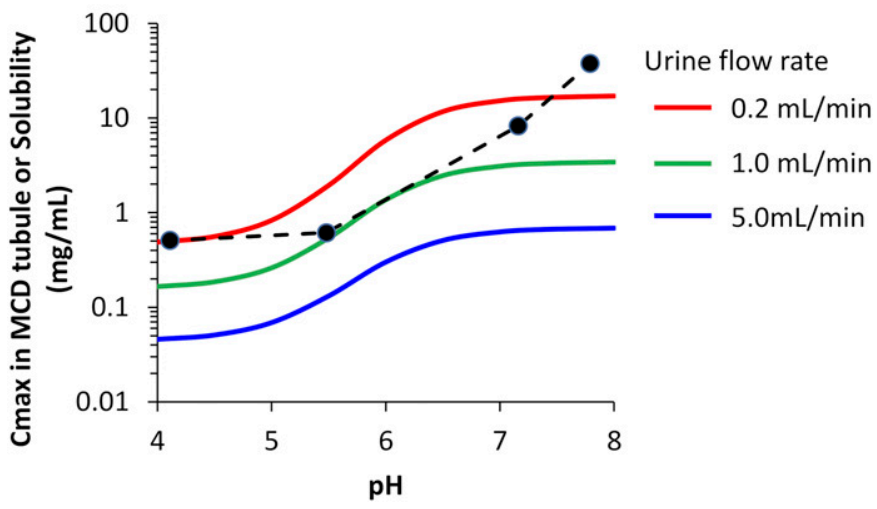

Fig. 6. Effect of urine flow and urine $\mathrm{pH}$ on simulated renal tubular concentration of acyclovir and sulfamethoxazole using MechKiM. (A) Effect of urine flow on simulated renal tubular concentration of low-dose acyclovir in virtual population representative. Simulated concentrationtime profiles of acyclovir in medullary collecting duct tubule after $5 \mathrm{mg} / \mathrm{kg}$ i.v. infusion over 90 minutes every 24 hours for 2 days. Horizontal dashed line represents the solubility of acyclovir $(2.5 \mathrm{mg} / \mathrm{ml})$. (B) Effect of urine flow and urine $\mathrm{pH}$ on simulated renal tubular concentration of sulfamethoxazole in virtual population representative. Simulated concentration-time profiles of sulfamethoxazole in medullary collecting ducts tubule after oral multiple administration of sulfamethoxazole at $25 \mathrm{mg} / \mathrm{kg}$ oral administration every 6 hours for 14 days. Dashed line represents the solubility of sulfamethoxazole from the published literature (Dahlan et al., 1987).

\section{Acknowledgments}

We thank Dr. Sibylle Neuhoff and Dr. Howard Burt for expert advice and technical assistance and Eleanor Savill for help with submission.

\section{Authorship Contributions}

Participated in research design: Matsuzaki, Scotcher, Galetin, Darwich, Rostami-Hodjegan.

Performed data analysis: Matsuzaki, Scotcher, Galetin, RostamiHodjegan.

Wrote or contributed to the writing of the manuscript: Matsuzaki, Scotcher, Galetin, Darwich, Rostami-Hodjegan.

\section{References}

Arnal J, Gonzalez-Alvarez I, Bermejo M, Amidon GL, Junginger HE, Kopp S, Midha KK, Shah VP, Stavchansky S, Dressman JB, et al. (2008) Biowaiver monographs for immediate release solid oral dosage forms: aciclovir. J Pharm Sci $\mathbf{9 7}$ 5061-5073.

Avdeef A (2012) Absorption and Drug Development: Solubility, Permeability, and Charge State, John Wiley \& Sons, Hoboken, NJ.
Ball K, Jamier T, Parmentier Y, Denizot C, Mallier A, and Chenel M (2017) Prediction of renal transporter-mediated drug-drug interactions for a drug which is an OAT substrate and inhibitor using PBPK modelling. Eur $J$ Pharm Sci 106 122-132.

Beckett AH, Salmon JA, and Mitchard M (1969) The relation between blood levels and urinary excretion of amphetamine under controlled acidic and under fluctuating urinary $\mathrm{pH}$ values using $[14 \mathrm{C}]$ amphetamine. J Pharm Pharmacol 21: $251-258$

Benowitz NL and Jacob P III (1993) Nicotine and cotinine elimination pharmacokinetics in smokers and nonsmokers. Clin Pharmacol Ther 53:316-323.

Birkett DJ and Miners JO (1991) Caffeine renal clearance and urine caffeine concentrations during steady state dosing. Implications for monitoring caffeine intake during sports events. Br J Clin Pharmacol 31:405-408.

Blanchard J and Sawers SJ (1983) Relationship between urine flow rate and renal clearance of caffeine in man. J Clin Pharmacol 23:134-138.

Blum MR, Liao SH, and de Miranda P (1982) Overview of acyclovir pharmacokinetic disposition in adults and children. Am J Med 73(1A):186-192.

Boroujerdi M (1982) The comparability of pharmacokinetics of creatinine in rabbit and man: a mathematical approach. J Theor Biol 95:369-380.

Brigden D, Bye A, Fowle AS, and Rogers H (1981) Human pharmacokinetics of acyclovir (an antiviral agent) following rapid intravenous injection. J Antimicrob Chemother 7:399-404.

Brigden D, Rosling AE, and Woods NC (1982) Renal function after acyclovir intravenous injection. Am J Med 73 (1A):182-185.

Burke JT, Wargin WA, Sherertz RJ, Sanders KL, Blum MR, and Sarubbi FA (1982) Pharmacokinetics of intravenous chloramphenicol sodium succinate in adult patients with normal renal and hepatic function. $J$ Pharmacokinet Biopharm 10: $601-614$

Burt HJ, Neuhoff S, Almond L, Gaohua L, Harwood MD, Jamei M, RostamiHodjegan A, Tucker GT, and Rowland-Yeo K (2016) Metformin and cimetidine: physiologically based pharmacokinetic modelling to investigate transporter mediated drug-drug interactions. Eur J Pharm Sci 88:70-82.

Cheng Y, Vapurcuyan A, Shahidullah M, Aleksunes LM, and Pelis RM (2012) Expression of organic anion transporter 2 in the human kidney and its potential role in the tubular secretion of guanine-containing antiviral drugs. Drug Metab Dispos 40:617-624.

Dahlan R, McDonald C, and Sunderland VB (1987) Solubilities and intrinsic dissolution rates of sulphamethoxazole and trimethoprim. $J$ Pharm Pharmacol 39: $246-251$.

Dave RA and Morris ME (2015) Semi-mechanistic kidney model incorporating physiologically-relevant fluid reabsorption and transporter-mediated renal reabsorption: pharmacokinetics of $\gamma$-hydroxybutyric acid and L-lactate in rats. $J$ Pharmacokinet Pharmacodyn 42:497-513.

de Miranda P, Good SS, Laskin OL, Krasny HC, Connor JD, and Lietman PS (1981) Disposition of intravenous radioactive acyclovir. Clin Pharmacol Ther 30:662-672. Dolder PC, Strajhar P, Vizeli P, Hammann F, Odermatt A, and Liechti ME (2017) Pharmacokinetics and pharmacodynamics of lisdexamfetamine compared with D-amphetamine in healthy subjects. Front Pharmacol 8:617.

Eck P, Silver SM, and Clark EC (1991) Acute renal failure and coma after a high dose of oral acyclovir. N Engl J Med 325:1178-1179.

Felmlee MA, Dave RA, and Morris ME (2013) Mechanistic models describing active renal reabsorption and secretion: a simulation-based study. AAPS J 15:278-287.

Gaohua L, Turner DB, Fisher C, Riedmaire AE, Musther H, Gardner I, and Jamei M (2016) A novel mechanistic approach to predict the steady state volume of distribution (Vss) using the Fick-Nernst-Planck equation, PAGE 25 (2016), Abstr 5709 [www.page-meeting.org/?abstract=5709].

Giustina A, Romanelli G, and Cimino A, and Brunori G (1988) Low-dose acyclovir and acute renal failure. Ann Intern Med 108:312-312.

Guo Y, Chu X, Parrott NJ, Brouwer KLR, Hsu V, Nagar S, Matsson P, Sharma P, Snoeys J, Sugiyama Y, et al.; International Transporter Consortium (2018) Advancing predictions of tissue and intracellular drug concentrations using in vitro, imaging and physiologically based pharmacokinetic modeling approaches. Clin Pharmacol Ther 104:865-889.

Hsu V, de L T Vieira M, Zhao P, Zhang L, Zheng JH, Nordmark A, Berglund EG, Giacomini KM, and Huang SM (2014) Towards quantitation of the effects of renal impairment and probenecid inhibition on kidney uptake and efflux transporters, using physiologically based pharmacokinetic modelling and simulations. Clin Pharmacokinet 53:283-293.

Hsueh CH, Hsu V, Zhao P, Zhang L, Giacomini KM, and Huang SM (2018) PBPK modeling of the effect of reduced kidney function on the pharmacokinetics of drugs excreted renally by organic anion transporters. Clin Pharmacol Ther 103:485-492.

Huang W and Isoherranen N (2018) Development of a dynamic physiologically based mechanistic kidney model to predict renal clearance. CPT Pharmacometrics Syst Pharmacol 7:593-602.

Hutabarat RM, Unadkat JD, Sahajwalla C, McNamara S, Ramsey B, and Smith AL (1991) Disposition of drugs in cystic fibrosis. I. Sulfamethoxazole and trimethoprim. Clin Pharmacol Ther 49:402-409.

Ito S, Kusuhara H, Kuroiwa Y, Wu C, Moriyama Y, Inoue K, Kondo T, Yuasa H, Nakayama H, Horita S, et al. (2010) Potent and specific inhibition of mMate1mediated efflux of type I organic cations in the liver and kidney by pyrimethamine. $J$ Pharmacol Exp Ther 333:341-350.

Jamei M, Marciniak S, Edwards D, Wragg K, Feng K, Barnett A, and RostamiHodjegan A (2013) The simcyp population based simulator: architecture, implementation, and quality assurance. In Silico Pharmacol 1:9.

Jamei M, Marciniak S, Feng K, Barnett A, Tucker G, and Rostami-Hodjegan A (2009) The Simcyp population-based ADME simulator. Expert Opin Drug Metab Toxicol 5: 211-223.

Kaplan SA, Weinfeld RE, Abruzzo CW, McFaden K, Jack ML, and Weissman L(1973) Pharmacokinetic profile of trimethoprim-sulfamethoxazole in man. J Infect Dis 128 (Suppl):547-555. 
Knepper MA, Kwon T-H, and Nielsen S (2015) Molecular physiology of water balance. N Engl J Med 372:1349-1358.

Komiya I (1986) Urine flow dependence of renal clearance and interrelation of renal reabsorption and physicochemical properties of drugs. Drug Metab Dispos 14:239-245. Krämer SD (2016) Quantitative aspects of drug permeation across in vitro and in vivo barriers. Eur J Pharm Sci 87:30-46.

Kraut JA and Kurtz I (2005) Metabolic acidosis of CKD: diagnosis, clinical characteristics, and treatment. Am J Kidney Dis 45:978-993.

Kunze A, Huwyler J, Poller B, Gutmann H, and Camenisch G (2014) In vitro-in vivo extrapolation method to predict human renal clearance of drugs. J Pharm Sci 103: 994-1001.

Laskin OL, de Miranda P, King DH, Page DA, Longstreth JA, Rocco L, and Lietman PS (1982a) Effects of probenecid on the pharmacokinetics and elimination of acyclovir in humans. Antimicrob Agents Chemother 21:804-807.

Laskin OL, Longstreth JA, Saral R, de Miranda P, Keeney R, and Lietman PS (1982b) Pharmacokinetics and tolerance of acyclovir, a new anti-herpesvirus agent, in humans. Antimicrob Agents Chemother 21:393-398.

Lelo A, Birkett DJ, Robson RA, and Miners JO (1986) Comparative pharmacokinetics of caffeine and its primary demethylated metabolites paraxanthine, theobromine and theophylline in man. Br J Clin Pharmacol 22:177-182.

Malnic G, De Mello Aires M, and Giebisch G (1972) Micropuncture study of renal tubular hydrogen ion transport in the rat. Am J Physiol 222:147-158.

Männistö PT, Mäntylä R, Mattila J, Nykänen S, and Lamminsivu U (1982) Com parison of pharmacokinetics of sulphadiazine and sulphamethoxazole after intravenous infusion. J Antimicrob Chemother 9:461-470.

Mathialagan S, Piotrowski MA, Tess DA, Feng B, Litchfield J, and Varma MV (2017) Quantitative prediction of human renal clearance and drug-drug interactions of organic anion transporter substrates using in vitro transport data: a relative activity factor approach. Drug Metab Dispos 45:409-417.

Mayer JM, Hall SD, and Rowland M (1988) Relationship between lipophilicity and tubular reabsorption for a series of 5-alkyl-5-ethylbarbituric acids in the isolated perfused rat kidney preparation. J Pharm Sci 77:359-364.

Mayersohn M, Conrad KA, and Achari R (1983) The influence of a cooked meat meal on creatinine plasma concentration and creatinine clearance. $\mathrm{Br} J$ Clin Pharmacol 15: $227-230$.

Mikami J, Oda K, and Hongo M (1975). Plasma concentration-time profile of chloramphenicol after oral, intramuscular, and intravenous administration of chloramphenicol in healthy men [in Japanese]. Japan Soc Clin Trials Res 3:1862-1866.

Molander L, Hansson A, and Lunell E (2001) Pharmacokinetics of nicotine in healthy elderly people. Clin Pharmacol Ther 69:57-65.

Nahata MC and Powell DA (1981) Bioavailability and clearance of chloramphenicol after intravenous chloramphenicol succinate. Clin Pharmacol Ther 30:368-372.

Neuhoff S, Gaohua L, Burt H, Jamei M, Li L, Tucker GT, and Rostami-Hodjegan A (2013) Accounting for transporters in renal clearance: towards a mechanistic kidney model (Mech KiM), in Transporters in Drug Development (Sugiyama Y and Steffansen B eds) pp 155-177, Springer, New York.

Neuhoff S, Ungell A-L, Zamora I, and Artursson P (2003) pH-dependent bidirectional transport of weakly basic drugs across Caco-2 monolayers: implications for drugdrug interactions. Pharm Res 20:1141-1148.

Newton R, Broughton LJ, Lind MJ, Morrison PJ, Rogers HJ, and Bradbrook ID (1981) Plasma and salivary pharmacokinetics of caffeine in man. Eur $J$ Clin Pharmacol 21:45-52.

Notohamiprodjo M, Pedersen M, Glaser C, Helck AD, Lodemann KP, Jespersen B, Fischereder M, Reiser MF, and Sourbron SP (2011) Comparison of Gd-DTPA and Gd-BOPTA for studying renal perfusion and filtration. J Magn Reson Imaging $\mathbf{3 4}$ 595-607.

Perazella MA (1999) Crystal-induced acute renal failure. Am J Med 106:459-465

Posada MM, Bacon JA, Schneck KB, Tirona RG, Kim RB, Higgins JW, Pak YA, Hall SD, and Hillgren KM (2015) Prediction of renal transporter mediated drug-drug interactions for pemetrexed using physiologically based pharmacokinetic modeling. Drug Metab Dispos 43:325-334.

Rodgers T, Leahy D, and Rowland M (2005) Physiologically based pharmacokinetic modeling 1: predicting the tissue distribution of moderate-to-strong bases J Pharm Sci 94:1259-1276.

Rodgers T and Rowland M (2006) Physiologically based pharmacokinetic modelling 2: predicting the tissue distribution of acids, very weak bases, neutrals and zwitterions. J Pharm Sci 95:1238-1257.

Rose C, Parker A, Jefferson B, and Cartmell E (2015) The characterization of feces and urine: a review of the literature to inform advanced treatment technology. Crit Rev Environ Sci Technol 45:1827-1879.

Rovei V, Chanoine F, and Strolin Benedetti M (1982) Pharmacokinetics of theoph ylline: a dose-range study. Br J Clin Pharmacol 14:769-778.

Sawyer MH, Webb DE, Balow JE, and Straus SE (1988) Acyclovir-induced renal failure. Clinical course and histology. Am J Med 84:1067-1071.

Scotcher D, Jones C, Posada M, Rostami-Hodjegan A, and Galetin A (2016a) Key to opening kidney for in vitro-in vivo extrapolation entrance in health and disease: part I: in vitro systems and physiological data. AAPS J 18:1067-1081.
Scotcher D, Jones C, Rostami-Hodjegan A, and Galetin A (2016b) Novel minimal physiologically-based model for the prediction of passive tubular reabsorption and renal excretion clearance. Eur J Pharm Sci 94:59-71.

Scotcher D, Jones CR, Galetin A, and Rostami-Hodjegan A (2017) Delineating the role of various factors in renal disposition of digoxin through application of physiologically based kidney model to renal impairment populations. J Pharmacol Exp Ther 360:484-495.

Senekjian HO, Knight TF, and Weinman EJ (1981) Micropuncture study of the handling of gentamicin by the rat kidney. Kidney Int 19:416-423.

Sharpstone P (1969) The renal handling of trimethoprim and sulphamethoxazole in man. Postgrad Med J 45:38-42.

Simerville JA, Maxted WC, and Pahira JJ (2005) Urinalysis: a comprehensive review. Am Fam Physician 71:1153-1162.

Soul-Lawton J, Seaber E, On N, Wootton R, Rolan P, and Posner J (1995) Absolute bioavailability and metabolic disposition of valaciclovir, the L-valyl ester of acyclovir, following oral administration to humans. Antimicrob Agents Chemother 39: 2759-2764.

Takeda M, Khamdang S, Narikawa S, Kimura H, Kobayashi Y, Yamamoto T, Cha SH, Sekine T, and Endou H (2002) Human organic anion transporters and human organic cation transporters mediate renal antiviral transport. $J$ Pharmacol Exp Ther 300:918-924

Tang-Liu DD, Tozer TN, and Riegelman S (1983) Dependence of renal clearance on urine flow: a mathematical model and its application. J Pharm Sci $\mathbf{7 2}$ : $154-158$.

Tang-Liu DD-S, Tozer TN, and Riegelman S (1982) Urine flow-dependence of theophylline renal clearance in man. J Pharmacokinet Biopharm 10:351-364.

Tanihara Y, Masuda S, Sato T, Katsura T, Ogawa O, and Inui K (2007) Substrate specificity of MATE1 and MATE2-K, human multidrug and toxin extrusions/ $\mathrm{H}(+)$-organic cation antiporters. Biochem Pharmacol 74:359-371.

Tsamandouras N, Dickinson G, Guo Y, Hall S, Rostami-Hodjegan A, Galetin A and Aarons L (2015) Development and application of a mechanistic pharmacokinetic model for simvastatin and its active metabolite simvastatin acid using an integrated population PBPK approach. Pharm Res 32:1864-1883.

Tucker GT (1981) Measurement of the renal clearance of drugs. Br J Clin Pharmacol 12:761-770.

Tucker WE Jr. (1982) Preclinical toxicology profile of acyclovir: an overview. Am J Med 73 (1A):27-30

Tucker WE Jr., Macklin AW, Szot RJ, Johnston RE, Elion GB, de Miranda P, and Szczech GM (1983) Preclinical toxicology studies with acyclovir: acute and subchronic tests. Fundam Appl Toxicol 3:573-578.

Varma MV, Feng B, Obach RS, Troutman MD, Chupka J, Miller HR, and El-Kattan A (2009) Physicochemical determinants of human renal clearance. J Med Chem 52: 4844-4852.

Volpe DA (2008) Variability in Caco-2 and MDCK cell-based intestinal permeability assays. J Pharm Sci 97:712-725.

Wan SH, Matin SB, and Azarnoff DL (1978) Kinetics, salivary excretion of amphetamine isomers, and effect of urinary pH. Clin Pharmacol Ther 23:585-590.

Watanalumlerd P, Christensen JM, and Ayres JW (2007) Pharmacokinetic modeling and simulation of gastrointestinal transit effects on plasma concentrations of drugs from mixed immediate-release and enteric-coated pellet formulations. Pharm Dev Technol 12:193-202.

Welling PG, Craig WA, Amidon GL, and Kunin CM(1973) Pharmacokinetics of trimethoprim and sulfamethoxazole in normal subjects and in patients with renal failure. J Infect Dis 128(Suppl):556-566.

Ye J, Liu Q, Wang C, Meng Q, Peng J, Sun H, Kaku T, and Liu K (2012) Inhibitory effect of JBP485 on renal excretion of acyclovir by the inhibition of OAT1 and OAT3. Eur J Pharm Sci 47:341-346.

Ye J, Liu Q, Wang C, Meng Q, Sun H, Peng J, Ma X, and Liu K (2013) Benzylpenicillin inhibits the renal excretion of acyclovir by OAT1 and OAT3. Pharmacol Rep 65:505-512. Yoshida K, Zhao P, Zhang L, Abernethy DR, Rekić D, Reynolds KS, Galetin A and Huang S-M (2017) In vitro-in vivo extrapolation of metabolism- and transporter-mediated drug-drug interactions-overview of basic prediction methods. J Pharm Sci 106:2209-2213.

Zamek-Gliszczynski MJ, Lee CA, Poirier A, Bentz J, Chu X, Ellens H, Ishikawa T, Jamei M, Kalvass JC, Nagar S, et al.; International Transporter Consortium (2013) ITC recommendations for transporter kinetic parameter estimation and translational modeling of transport-mediated PK and DDIs in humans. Clin Pharmacol Ther 94:64-79.

Zevin S, Jacob P III, and Benowitz N (1997) Cotinine effects on nicotine metabolism. Clin Pharmacol Ther 61:649-654.

Address correspondence to: Amin Rostami-Hodjegan, Centre for Applied Pharmacokinetic Research, The University of Manchester, Stopford Building, Oxford Road, Manchester M13 9PT, United Kingdom. E-mail: amin.rostami@ manchester.ac.uk 